JSAP: Journal Syariah and Accounting Public

ISSN: 2622-3538

Available Online at https://journal.umgo.ac.id/index.php/JSAP/index

Vol. 3, No. 1 Juli 2020

DOI: $10.31314 /$ jsap.3.1.9-18.2020

\title{
EKSISTENSI MANAJEMEN LABA DAN NILAI TUKAR RUPIAH (KURS) SEBAGAI KATALISATOR REAKSI INVESTOR PASAR MODAL PADA PERUSAHAAN FARMASI YANG TERDAFTAR DI BURSA EFEK INDONESIA PERIODE 2015-2019
}

\author{
Fitri Meliansyah ${ }^{1}$, Moh. Zubair Hippy ${ }^{2}$ \\ 1,2, Program Studi Akuntansi Fakultas IImu Sosial Universitas Muhammadiyah Gorontalo, \\ Indonesia \\ Email; fmelynsyah@gmail.com
}

Info Artikel: Diterima: 13 Februari 2020, Disetujui: 23 Februari 2020, Publish 15 Juli 2020

\begin{abstract}
:
This study aims to determine the partial or simultaneous effect of earnings management and the Rupiah exchange rate (Exchange rate) on the market reaction of pharmaceutical companies listed on the Indonesia Stock Exchange for the 2015-2019 period. This research is a quantitative research. The source of data in this study is secondary data in the form of annual financial statements of companies listed on the IDX. Then the stock price is obtained from the yahoo finance site. The sampling method is purposive sampling. The data analysis technique used is multiple regression analysis of panel data constructs. The results of this study indicate that partially earnings management has no significant effect on capital market reactions while the Rupiah exchange rate (exchange rate) has a significant effect on capital market reactions. Simultaneously, earnings management and the exchange rate of the rupiah (exchange rate) have a significant effect on the reaction of the capital market.
\end{abstract}

Keywords: Market Reaction, Earnings Management, Exchange Rate

\begin{abstract}
Abstrak:
Penelitian bertujuan untuk mengetahui pengaruh secara parsial maupun simultan dari manajemen laba dan nilai tukar Rupiah (Kurs) terhadap reaksi pasar pada perusahaan farmasi yang terdaftar di Bursa Efek Indonesia periode 2015-2019. Penelitian ini merupakan penelitian kuantitatif. Sumber data dalam penelitian ini adalah data sekunder berupa laporan keuangan tahunan pada perusahaan yang terdaftar di BEI. Kemudian harga saham diperoleh dari situs yahoo finance Metode pengambilan sampel adalah purposive sampling. Teknik analisis data yang digunakan adalah analisis regresi berganda konstruk data panel. Hasil penelitian ini menunjukan bahwa secara parsial Manajemen laba tidak berpengaruh signifikan terhadap Reaksi pasar modal sedangkan Nilai tukar Rupiah (Kurs) berpengaruh signifikan terhadap Reaksi pasar modal. Secara simultan, Manajemen laba dan Nilai tukar Rupiah (Kurs) berpengaruh signifikan terhadap Reaksi pasar modal.
\end{abstract}

Kata kunci : Reaksi Pasar, Manajemen Laba, Kurs

\section{PENDAHULUAN}

Reaksi investor tersebut merupakan suatu ketertarikan investor atau dalam hal ini dapat dikatakan sebagai minat dari investor. Reaksi pasar dapat diukur dengan menggunakan return sebagai nilai 
perubahan harga atau dengan menggunakan abnormal return (Jogiyanto, dalam Wahyuningsih, 2007: 1). Sehingga investor bereaksi terhadap suatu informasi untuk mencapai harga keseimbangan yang baru merupakan hal yang penting, Pada saat pasar bereaksi dengan cepat dan akurat untuk mencapi harga keseimbangan baru yang sepenuhnya mencerminkan informasi yang tersedia, maka kondisi pasar seperti ini disebut dengan pasar efesien. Earning response atau reaksi pasar ini diukur dengan menggunakan cumulative abnormal return (CAR) yang dihitung dengan periode pengamatan kurang lebih 10 hari.

Adanya masalah mengenai reaksi pasar tersebut tentunya diakibatkan oleh berbagai faktor. Dalam konsep teori klasik signaling theory sebagaimana dikatakan oleh Brigham dan Houston dalam Kurniyawati (2015: 49) isyarat atau signal adalah suatu tindakan yang diambil perusahaan untuk memberi petunjuk bagi investor tentang bagaimana manajemen memandang prospek perusahaan. Sehingga salah satu faktor ekonomi mikro yakni tindakan manajemen dalam melakukan manajemen laba. Hal tersebut sebagaimana dikatakan oleh Wahyuningsih (2007: 27) bahwa Adanya praktek manajemen laba dalam penyajian laporan keuangan menyebabkan informasi yang terdapat dalam laporan keuangan tidak mencerminkan kondisi perusahaan yang sebenarnya. Sehingga, jika investor mengetahui adanya praktek manajemen laba yang dilakukan oleh perusahaan tertentu, mereka akan mengetahui bahwa kondisi sesungguhnya perusahaan tersebut dapat lebih baik atau lebih buruk dari yang dilaporkan, sehingga investor akan memberikan reaksi berupa koreksi harga saham perusahaan yang bersangkutan
Selain faktor mikro ekonomi sebagai faktor manajemen rumah tangga perusahaan. Faktor lainnya yakni faktor makro ekonomi yang merupakan faktor ekstern atau bentuk analisis teknikal yang mempengaruhi harga pasar saham perusahaan. Makro ekonomi adalah salah satu cabang ilmu ekonomi yang membahas perilaku perekonomian secara agregat, misalnya kemakmuran dan resesi, output barang dan jasa, total perekonomian, laju pertumbuhan output, laju inflasi dan pengangguran, neraca pembayaran dan juga nilai kurs (Dornbusch, Stanley, dan Mulyadi, 2003:3). Sehingga salah satu faktor makro tersebut menurut Sukirno (2011: 23) yakni kebijakan pemerintah yang berdampak pada kurs atau nilai tukar rupiah.

\section{Reaksi Pasar}

Reaksi pasar dapat diukur dengan menggunakan return sebagai nilai perubahan harga atau dengan menggunakan abnormal return (Jogiyanto, dalam Wahyuningsih, 2007: 1). Earning response atau reaksi pasar ini diukur dengan menggunakan cumulative abnormal return (CAR) yang dihitung dengan periode pengamatan kurang lebih 10 hari. Menghitung variabel Cumulative Abnormal Return (CAR) dengan rumus :

$$
\mathrm{CAR}_{\mathrm{i}(-10,+10)}={ }_{\mathrm{t}=-10} \Sigma^{+10} \mathrm{AR}_{\mathrm{it}}
$$

\section{Manajemen Laba}

Scott dalam Sulistiawan, dkk. (2012: 178) menyatakan bahwa manajemen laba adalah pilihan atas kebijakan akuntansi yang dilakukan manajemen untuk mencapai tujuan tertentu.

Manajemen laba diukur dengan menggunakan nilai discretionary accruals (DA) yakni Modified Jones Model, (Sulistiawan, dkk., 2012: 46)). Model tersebut dituliskan sebagai berikut :

1. Menentukan nilai total akrual dengan formulasi: 
$\mathrm{TA}_{\mathrm{it}}=\mathrm{NI}_{\mathrm{it}}-\mathrm{CFO}_{\mathrm{it}}$

2. Menentukan nilai parameter $\alpha 1, \alpha 2$, a3 menggunakan Jones Model (1991), dengan formulasi:

$\mathrm{TA}_{\mathrm{it}}=\alpha 1+\alpha \mathbf{2} \Delta \mathrm{Revt}+\alpha 3 \mathrm{PPE}_{\mathrm{it}}+\mathrm{e}$

Lalu untuk menskala data, semua variable tersebut dibagi dengan aset tahun sebelumnya $\left(A_{i t}\right)$, sehingga formulasinya berubah menjadi:

$$
+{ }_{e} \frac{\text { TAit }}{\text { Ait }}=\alpha 1\left(\frac{1}{\text { Ait-1 }}\right)+\alpha 2\left(\frac{\Delta \text { Revt }}{\text { Ait-1 }}\right)+\alpha 3\left(\frac{\text { PPEt }}{\text { Ait-1 }}\right)
$$

3. Menghitung nilai NDA dengan formulasi: $\alpha 3\left(\frac{\text { PPEt }}{\text { Ait-1 }}\right)$

$\mathrm{NDA}_{i t}=\alpha 1\left(\frac{1}{\text { Ait-1 }}\right)+\alpha 2\left(\frac{\Delta \text { Revt }}{\text { Ait-1 }}-\frac{\Delta \text { Rect }}{\text { Ait-1 }}\right)+$

Nilai parameter $\alpha 1, \alpha 2, \alpha 3$ adalah hasil dari perhitungan pada langkah ke-2. Isikan semua nilai yang ada dalam formula sehingga nilai NDA akan bisa didapatkan.

4. Menentukan nilai akrual diskresioner dengan formulasi:

$$
\mathrm{DA}_{\text {it }}=\mathrm{TA}_{\mathrm{it}}-\mathrm{NDA}_{\mathrm{it}}
$$

\section{Nilai Tukar Rupiah (Kurs)}

Kurs (Exchange Rate) adalah pertukaran antara dua mata uang yang berbeda, yaitu merupakan perbandingan nilai atau harga antara kedua mata uang tersebut. (Sukirno dalam Triyono, 2008: 157).

\section{METODE PENELITIAN}

Analisis data dalam penelitian ini yakni regresi berganda dengan konstruk data panel. Analisis regeresi linear berganda ini dinyatakan dalam bentuk:

$$
\dot{Y}=a+b X 1+b X 2+e
$$

Keterangan :

$\dot{Y}=$ Variabel Dependent (Reaksi pasar modal)

$\mathrm{X} 1=$ Variabel Independent (Manajemen Laba)

X2 = Variabel Independent (Kurs)

$\mathrm{a}=$ Nilai Konstanta $b=$ Nilai Koefisien.

HASIL DAN PEMBAHASAN

\section{Penaksiran Model Regresi}

Hasil regresi data panel dengan bantuan E-Views 9 ditampilkan pada tabel 4.8 berikut ini:

\section{Tabel 4.8: Model Analisis Regresi} Prob(F-statistic) $\quad 0.000001$

Sumber: Pengolahan Data E-Views 9, 2020

Berdasarkan hasil analisis menggunakan bantuan program E-Views 9 di atas maka diperoleh model regresi sebagai berikut:

$$
Y=162,091+8,136 X_{1}-17,439 X_{2}+e
$$

Berdasarkan tabel di atas didapat nilai

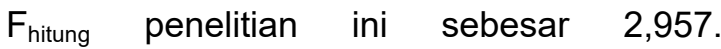
Sedangkan nila $\mathrm{F}_{\text {-tabel }}$ pada tingkat signifikansi $5 \%$ dan df1 yakni N-k-1 = 39-2-1 $=36$ dan df2 sebesar nt-n-k = 195-39-2 = 154 adalah sebesar 1,494 dan pada tingkat signifikansi $1 \%$ dan df1 yakni N-k-1 = 39-2-1 $=36$ dan df2 sebesar nt-n-k = 195-39-2 = 154 adalah sebesar 1,759. Jika dibandingkan nilai probabilitas atau probability value ( $\mathrm{P}$-Value) yang diperoleh lebih kecil dari nilai alpha 0,05 maupun 0,01. Dengan demikian secara keseluruhan dapat disimpulkan bahwa variabel bebas (Manajemen laba dan Nilai tukar Rupiah (Kurs)) secara bersama-sama berpengaruh sangat signifikan terhadap Reaksi pasar modal khususnya pada Perusahaan Farmasi yang terdaftar di Bursa Efek Indonesia periode 2015-2019.

Berdasarkan tabel di atas, maka nilai koefisien determinasi adjusted $R^{2}$ sebesar 0,287512 . Nilai ini berarti bahwa sebesar $28,7512 \%$ besarnya Reaksi pasar modal khususnya pada Perusahaan Farmasi yang terdaftar di Bursa Efek Indonesia periode 2015-2019 dapat dijelaskan oleh Manajemen laba dan Nilai tukar Rupiah (Kurs) pada 
Perusahaan Farmasi yang terdaftar di Bursa Efek Indonesia periode 2015-2019. Adapun kemampuan dari variabel lain dalam menjelaskan Reaksi pasar modal sebesar hanya $71,2488 \%$ (100\%-28,7512\%).

Hasil pengujian pengaruh setiap variabel bebas (Manajemen laba dan Nilai tukar Rupiah (Kurs) terhadap variabel terikat yakni Reaksi pasar modal pada Perusahaan Farmasi yang terdaftar di Bursa Efek Indonesia periode 2015-2019 adalah sebagai berikut:

\section{Pengaruh Manajemen laba terhadap Reaksi pasar modal}

Nilai probability value (P-Value) Manajemen laba lebih besar dari nilai probabilitas 0,05 maupun 0,01 . Sehingga dapat disimpulkan bahwa Manajemen laba tidak berpengaruh signifikan terhadap Reaksi pasar modal pada Perusahaan Farmasi yang terdaftar di Bursa Efek Indonesia periode 2015-2019.

\section{Pengaruh Nilai tukar Rupiah (Kurs) terhadap Reaksi pasar modal}

Nilai probability value (P-Value) Nilai tukar Rupiah (Kurs) lebih besar dari nilai probabilitas 0,05 maupun 0,01. Sehingga dengan demikian dapat disimpulkan bahwa Nilai tukar Rupiah (Kurs) berpengaruh signifikan terhadap Reaksi pasar modal pada Perusahaan Farmasi yang terdaftar di Bursa Efek Indonesia periode 2015-2019.

\section{Pembahasan}

\section{A. Pengaruh Manajemen Laba Terhadap Reaksi pasar modal}

Manajemen laba terjadi sebagai bagian dari dampak persoalan keagenan yaitu adanya ketidakseimbangan kepentingan antara pemilik dan manajemen. Pihak pemilik dan manajemen ingin memiliki tingkat keuntungan tertentu sehingga pihak manajemen selaku pengelola perusahaan melakukan praktek manajemen laba dengan tujuan untuk mencapai kemakmuran dirinya sendiri. Para pemilik sebagian tidak mengetahui sepenuhnya yang ada pada perusahaan karena hanya menanam modal dan bertujuan hanya ingin memperoleh keuntungan atau laba. Pada umumnya tujuan pihak manajemen melakukan praktek manajemen laba untuk memaksimalkan kesejahteraan pihak manajemen, memanipulasi besaran laba yang dilaporkan kepada para pemegang saham dan mempengaruhi hasil perjanjian yang bergantung pada angka-angka akuntansi yang dilaporkan, pihak-pihak yang berkepentingan serta nilai pasar.

Manajemen laba dapat dilihat dari cut of angka nol dimana jika nilainya positif atau di atas angka nol maka perusahan tersebut telah melakukan peningkatan laba dengan memanfaatkan berbagai aspek pendapatan perusahaan. Kemudian jika nilainya negatif atau kurangd dari angka nol maka perusahaan cenderung melakukan penurunan laba. Kemudian jika nilainya nol maka perusahaan melakukan pererataan laba atau income smoothing. Adanya manajemen laba tentunya akan memberikan dampak jangka pendek yang baik namun secara jangka panjang akan berdampak pada stigma investor yang makin kurang percaya lagi dengan perusahaan.

Hasil pengujian mengenai pengaruh manajemen laba terhadap reaksi pasar dapat dilihat dari hasil uji t ditemukan bahwa Manajemen laba tidak berpengaruh signifikan terhadap Reaksi pasar modal pada Perusahaan Farmasi yang terdaftar di Bursa Efek Indonesia periode 2015-2019. Koefisien regresi yakni positif menunjukkan bahwa Manajemen laba mempunyai hubungan yang searah dengan Reaksi pasar modal. Dengan kata lain bahwa ketika 
variabel Manajemen laba semakin besar atau ada upaya peningkatan laba maka Reaksi pasar modal Perusahaan akan mengalami peningkatan.

Secara teori pula, hal ini sejalan dengan signaling. Kurangnya informasi bagi pihak luar mengenai perusahaan menyebabkan mereka melindungi diri mereka dengan memberikan harga yang rendah untuk perusahaan. Perusahaan dapat meningkatkan nilai perusahaan dengan mengurangi informasi asimetri. Salah satu cara untuk mengurangi informasi asimetri adalah dengan memberikan sinyal pada pihak luar (Arifin, 2005: 11). Sehingga dengan adanya informasi tersebut maka akan menimbulkan stigma baik bagi investor. Namun demikian hal ini tidak bisa terus dilakukan karena dapat berdampak pada citra perusahaan sebagaimana yang pernah terjadi pada PT Kimia Farma tahun 2000.

Hasil ini pula mendukung teori yang diungkapkan oleh Scot dalam Pratama dan Suaryana (2016: 2049) bahwa melaksanakan manajemen laba adalah manajemen memiliki keyakinan bahwa akan adanya imbalan atas tindakan atau upaya yang dilakukan. Motivasi dilakukannya praktik manajemen laba yaitu motivasi perpajakan, pergantian direksi, IPO, rencana bonus, dan motivasi politik. Manajemen laba tidak dapat dipertahankan dalam jangka waktu yang panjang. Manajemen harus segera melakukan penyesuaian terhadap rekayasa dalam laporan keuangan pada periode-periode beriutnya agar publik tidak segera tahu aktivitas manajemen laba yang dilakukan perusahaan. Penyusaian ini secara tidak langsung akan memberikan dampak terhadap penurunan kinerja saham.

Pengujian regresi yang tidak signifikan menunjukan bahwa adanya kemampuan investor yang sudah mengetahui gelagat dari manajer jika melakukan manajemen laba sebagaimana pengalaman-pengalaman dari investor pda perusahan Kimia Farma dan Indofarma sehingga investor akan lebih hatihati dalam mengambila keputusan investasi pada perusahaan. Selain itu manajemen laba juga secara tidak lansung dan bisa menjadi kemungkinan dapat dideteksi dari adanya nilai pajak tangguhan yang begitu besar pada laporan laba rugi perusahaan sehingga adanya gejala bahwa perusahaan sedang melakukan penghindaran pajak yang secara aturan memang legal tapi hal tersebut akan menjadi benturan ketika adanya rekonsiliasi fiskal yang dilakukan oleh fiskus pada periode pelaporan keuangan selanjutnya.

Selain itu, hasil yang tidak signifikan karena adanya peran serta dari unsur-unsur Goog Corporate Governance dalam perusahaan yang melakukan tugasnya dengan baik seperti peran dari direksi dan komisaris yang terus melkaukan pengawasan secar berkala agar dapat mengawasi tindakan opportunistic dari manajer yang ingin mendapatkan pengakuan prestasi atau motivasi atas bonus dari tindakan manajemen laba. Kemudian peran dari kepemilikan institusional yang merupaakn pemegang saham yang mendominasi dalam perusahaan sehingga dengan adanya intervensi yang baik maka manajer tidak melakukan hal-hal yang berdampak pada citra perusahaan serta adanya peran komite audit yang melakukan pemeriksaan bukan hanya pada kepatuhan manajemen namun juga pada kewajaran pelaporan keuangan sebelum dipublikasikan oleh perusahaan.

Hasil pengujian dalam penelitian ini secara inti menjadi penelitian pendukung dari beberapa jurnal ilmiah sebelumnya seperti yang pernah dilakukan oleh Nindhy Marshena Mayastari (2014) yang berjudul Pengaruh asimetri informasi dan manajemen 
laba Terhadap perubahan harga saham pada Perusahaan food and beverages yang terdaftar di bursa efek indonesia. Hasil penelitiannya menemukan bahwa adanya dampak positif dari manajemen laba terhadap perubahan harga saham perusahaan.

\section{B. Pengaruh Nilai tukar Rupiah (Kurs) Terhadap Reaksi pasar modal}

Kurs akan memberikan dampak bagi reaksi pasar modal. Sebagaimana hasil pengujian regresi berganda ditemukan bahwa Nilai tukar Rupiah (Kurs) berpengaruh signifikan terhadap Reaksi pasar modal pada Perusahaan Farmasi yang terdaftar di Bursa Efek Indonesia periode 2015-2019. Koefisien regresi yakni negatif menunjukkan bahwa Nilai tukar Rupiah (Kurs) mempunyai hubungan yang tidak searah dengan Reaksi pasar modal. Dengan kata lain bahwa ketika variabel Nilai tukar Rupiah (Kurs) semakin besar maka terjadi penurunan pada Reaksi pasar modal karena peningkatan nilai kurs atau melemahnya rupiah maka akan membuat harga bahan baku semakin mahal.

Pengaruh yang signifikan menunjukan bahwa adanya dampak yang sangat kuat dari pergerakan kurs terhadap perubahan tingkah laku investor terutama investor yang sifatnya spekulan. Sehingga dengan adanya fenomena ini secara event tudy akan memberikan dampak yang buruk bagi perusahaan. Fluktuasi besarnya nilai tukar uang akan menimbulkan risiko terjadinya laba dan rugi. Adanya korelasi antara nilai tukar dengan reaksi pasar saham dan nilai tukar mempengaruhi reaksi pasar saham (Chandrarin dan Tearney dalam Suciwati dan Machfoedz 2012: 348).

Sementara itu hasil pengujian yang negatif menunjukan bahwa Melemahnya nilai tukar rupiah yang signifikan membawa dampak yang beraneka ragam terhadap emiten, terutama emiten yang mempunyai utang dalam bentuk dolar akan merasakan dampak yang paling besar. Menurunnya nilai rupiah berdampak penurunan pada IHSG dan return saham yang didukung oleh teori Maryanti (2009: 16) menyatakan bahwa jika nilai rupiah melemah, maka investor akan lebih memilih untuk berinvestasi dalam bentuk dolar dibandingkan dengan berinvestasi pada surat-surat berharga, karena surat-surat berharga merupakan investasi jangka panjang. Jika harga saham cenderung turun untuk kemudian naik kembali akan membuat saham yang diperdagangkan akan semakin likuid dan diminati oleh para investor.

Hal ini didukung dengan teori sinyal (signalling theory) bahwa menguatnya nilai tukar rupiah terhadap kurs dolar AS atau penurunan kurs dollar maka pengumuman tersebut memiliki kandungan informasi yang baik sehingga dapat memberikan sinyal positif bagi investor (Marwata, 2001). Hal ini disebabkan karena mempunyai prospek yang baik di masa yang akan datang sehingga dapat menarik investor untuk melakukan pembelian saham. Reaksi pasar dapat dilihat melalui perubahan harga saham setelah pengumuman tersebut diumumkan. Dengan adanya kenaikan harga saham tersebut, maka akan diikuti dengan kenaikan return saham dan secara otomatis akan menaikan Indeks Harga Saham Gabungan sehingga abnormal return juga mengalami peningkatan

Sehingga dengan demikian dapat dikatakan bahwa depresiasi mata uang berpengaruh negatif terhadap pasar modal baik dalam jangka panjang maupun jangka pendek. Disamping itu produk- produk yang dihasilkan oleh perusahaan publik tersebut banyak menggunakan bahan yang memiliki kandungan impor yang tinggi. Merosotnya 
nilai rupiah dimungkinkan menyebabkan jumlah utang perusahaan dan biaya produksi menjadi bertambah besar jika dinilai dengan rupiah, dan akhirnya akan berujung pada menurunnya profitabilitas perusahaan. Dengan penurunan tersebut maka dapat dipastikan bahwa investor akan sgeara bereaksi karena akan berdampak pada kerugian investor dalam investasi saham tersebut.

\section{Pengaruh Manajemen laba dan Nilai tukar Rupiah (Kurs) Terhadap Reaksi pasar modal}

Hasil pengujian regresi berganda ditemukan bahwa secara keseluruhan dapat disimpulkan bahwa variabel bebas (Manajemen laba dan Nilai tukar Rupiah (Kurs)) secara bersama-sama berpengaruh signifikan terhadap variabel terikat Reaksi pasar modal khususnya pada Perusahaan Farmasi yang terdaftar di Bursa Efek Indonesia periode 2015-2019. Kedua variabel tersebut berpengaruh signifikan karena kedua aspek tersebut menjadi informasi yang sangat krusial bagi investor dalam memustuskan berinvestasi.

Sementara itu, hasil dari koefisien determinasi ditemukan bahwa nilai koefisien determinasi adjusted $R^{2}$ sebesar 0,287512. Nilai ini berarti bahwa sebesar $28,7512 \%$ besarnya Reaksi pasar modal khususnya pada Perusahaan Farmasi yang terdaftar di Bursa Efek Indonesia periode 2015-2019 dapat dijelaskan oleh Manajemen laba dan Nilai tukar Rupiah (Kurs) pada Perusahaan Farmasi yang terdaftar di Bursa Efek Indonesia periode 2015-2019. Adapun kemampuan dari variabel lain dalam menjelaskan Reaksi pasar modal sebesar hanya $71,2488 \%$ (100\%-28,7512\%).

Variabel lain yang mempengaruhi reaksi pasar modal dapat dibagi dalam 2 aspek yakni faktor fundamental yakni faktor mikro yang meliputi rasio keuangan seperti rasio likuditas (current ratio, Quick ratio dan Cash ratio), rasio profitabilitas (Return On Asset, Return On equity dan Net Profit Margin), rasio Solvabilitas (Debt to Asset ratio, Debt to Equity Ratio dan Time Interest Earning), rasio aktivitas (rasio perputaran modal kerja dan perputaran aktiva) dan rasio pasar yang meliputi earning per share, dividen per share, dividen payout ratio dan price book value. Serta faktor mikro yang berupa peran dari struktur kepemilikan, direksi, dewan komisaris, komite audit dan unsur audit eksternal. Serta faktor teknikal yang merupakan gejala ekonomi makro seperti inflasi, pertumbuhan ekonomi, politik dan kejadian tak terduga seperti kejadian bom pada awal Januari tahun 2016.

\section{KESIMPULAN}

Berdasarkan hasil penelitian dan pembahasan pada bab sebelumnya, maka dapat ditarik beberapa simpulan sebagai berikut:

1. Manajemen laba tidak berpengaruh signifikan terhadap Reaksi pasar modal pada Perusahaan Farmasi yang terdaftar di Bursa Efek Indonesia periode 2015-2019. Koefisien regresi yakni positif menunjukkan bahwa ketika variabel Manajemen laba semakin besar atau ada upaya peningkatan laba maka Reaksi pasar modal Perusahaan akan mengalami peningkatan

2. Nilai tukar Rupiah (Kurs) berpengaruh signifikan terhadap Reaksi pasar modal pada Perusahaan Farmasi yang terdaftar di Bursa Efek Indonesia periode 2015-2019. Koefisien regresi yakni negatif menunjukkan bahwa ketika variabel Nilai tukar Rupiah (Kurs) semakin besar maka terjadi penurunan pada Reaksi pasar modal karena peningkatan nilai kurs atau melemahnya 
rupiah maka akan membuat inflasi menjadi lebih tinggi karena semua produk menjadi lebih mahal

3. Secara simultan variabel bebas (Manajemen laba dan Nilai tukar Rupiah (Kurs)) secara bersama-sama berpengaruh signifikan terhadap variabel terikat Reaksi pasar modal khususnya pada Perusahaan Farmasi yang terdaftar di Bursa Efek Indonesia periode 2015-2019 dengan deterninan sebesar $28,7512 \%$.

\section{SARAN}

Berdasarkan hasil penelitian dan simpulan yang telah diuraikan di atas, maka saran penelitian ini adalah sebagai berikut:

1. Sebaiknya pada Perusahaan Farmasi yang terdaftar di Bursa Efek Indonesia tidak seara terus menerus melakukan tindakan manajemen laba, alangkah baiknya melakukan penekanan biaya dan maksimalisasi dalam pendapatan serta dengan melakukan dan mengalokasikan lebih banyak biaya CSR sehingga akan berdampak pada baiknya citra perusahaan di mata investor.

2. Sebaiknya pada Perusahaan Farmasi yang terdaftar di Bursa Efek Indonesia berupaya untuk melakukan berbagai tindakan preventif ketika terjadi kenaikan kurs. Salah satu cara yang dapat dilakukan yakni dengan melakukan stock split agar saham perusahaan tidak terlalu jatuh nilanya. Serta bagi elemen dalam perusahaan seperti dewan direksi, komisaris serta manajer merumuskan sebuah kebijakan ketika terjadi peristiwa-peristiwa yang tak terduga yang berkaitan dengan kenaikan dan penurunan reaksi pasar.
Sebaiknya

perusahaan memaksimalkan nilai perusahaan dengan meningkatkan kinerja keuangan. Dengan langkah ini maka akan berdampak pada ketertarikan investor sehingga permintaan saham makin tinggi yang implikasinya pada harga saham dan tingkat pengembalian investasi saham perusahaan.

\section{REFERENSI}

Adiningsih, Sri dkk. 1998. Perangkat Analisis dan Teknik Analisis Investasi di. Pasar Modal Indonesia. Jakarta: P.T. Bursa Efek Jakarta

Adwiyah, Rabiatul. 2014. Analisis Pengaruh Variabel-Variabel Fundamental Dan Teknikal Terhadap Harga Saham Industri Perbankan di BEl. Tesis Sekolah Pasca Sarjana Institut Pertanian Bogor

Arifin, Zaenal, 2005. Teori Keuangan dan Pasar Modal, Yogyakarta: Penerbit Ekonisia.

Denies, Priantinah. 2009. Manajemen Laba Ditinjau Dari Sudut Pandang Oportunistik Dan Efisien Dalam Positive Accounting Theory. Jurnal Pendidikan Akuntansi Indonesia. Vol. VII No. 1, Tahun 2009, hal: 99-109.

Dwiadnyana, I Kadek Adi dan I Ketut Jati. 2014. Reaksi Pasar Atas Manajemen Laba Pada Pengumuman Informasi Laba. -Jurnal Akuntansi Universitas Udayana 7.1 (2014):165-176

Fabozzi, Frank, J and Franco Modigliani, 1996 Capital Market, Second Edition New Jersey Printice - Hall inc

Fakhruddin, Hendy M. 2008. Istilah Pasar Modal A-Z. Jakarta: Elex Media Komputindo

Fischer. 1992. Makroekonomi : Uang, Harga-harga dan Nilai Kurs. Alih Bahasa : Julius A. Mulyadi Jakarta: Penerbit Erlangga.

Fransiska, Yulia. 2007. Analisis FaktorFaktor Yang Mempengaruhi Manajemen Laba Pada Perusahaan 
Yang Melakukan IPO Di Bursa Efek Jakarta. Jurnal. Universitas Islam Indonesia. Yogyakarta

Irham, Fahmi. 2013. Analisis Laporan Keuangan. Bandung: Penerbit CV Alfabeta.

Jagrataraning, Ekaliya. 2016. Pengaruh Pengumuman Dividen Saham Terhadap Abnormal Return Dan Trading Volume Activity Saham Di Bursa Efek Indonesia. Jurnal Fakultas Ekonomi Universitas Negeri Yogyakarta

Jogiyanto, H.M. 2010. Teori Portofolio dan Analisis Investasi. Edisi Ketujuh. BPFE. Yogyakarta

Kurniawati, Astuti. 2015. Reaksi pasar jakarta islamic index atas terpilinnya joko widodo sebagai presiden republik indonesia periode 2014-2019. Thesis, Universitas Airlangga.

Lindananty danMohammad Soedarman. 2015. Konsistensi Reaksi Pasar Modal Indonesia Terhadap Penerbitan Indeks Sri-Kehati. Jurnal Manajemen dan Kewirausahaan volume 1 Nomor 17

Ma'ruf, 2006. "Analisis Faktor-Faktor Yang Mempengaruhi Manajemen Laba pada Perusahaan Go-Public di Bursa Efek Jakarta (BEJ)", Tesis: Universitas Diponegoro, Semarang.

Marwata. 2001. Hubungan Antara Karakteristik Perusahaan dan Kualitas Ungkapan Sukarela dalam Laporan Tahunan Perusahaan Publik di Indonesia, Simposium Nasional Akuntansi IV

Mayastari, Nindhy Marshena. 2014. 2014. Pengaruh Asimetri Informasi Dan Manajemen Laba Terhadap Perubahan Harga Saham Pada Perusahaan Food And Beverages Yang Terdaftar Di Bursa Efek Indonesia. Jurnal Jurusan Akuntansi pada Fakultas Ekonomi Universitas Widyatama

Mulyani, Sri; Nur Fadjrih Asyik dan Andayani. 2007. Faktor-Faktor Yang Mempengaruhi Earnings Response
Coefficient Pada Perusahaan Yang Terdaftar Di Bursa Efek Jakarta. JAAI Volume 11 No. 1, Juni 2007: 35-45.

Noviant, Brahm Ardhi dan Marsono. 2013. Analisis reaksi pasar dan risiko investasi antara perusahaan Perata laba dan bukan perata laba (Studi Pada Perusahaan Manufaktur Yang Terdaftar Di BEI) Jurnal Akuntansi \& Auditing Volume 9/No. 2/MEI 2013 : $226-243$

Nuswandari, Cahyani. 2009. Pengungkapan Pelaporan Keuangan Dalam Perspektif Signalling Theory. Kajian Akuntansi, Pebruari 2009, Hal: $48-57$ Vol. 1 No. 1 ISSN : $1979-4886$

Poerwadarminta. 1987. Kamus Umum Bahasa Indonesia. Jakarta: Penerbit Balai Pustaka

Pratama, Andika dan Agung Suaryana. 2016. Pengaruh Manajemen Laba Terhadap Kinerja Saham Jangka Panjang Perusahaan Yang Melakukan Seasoned Equity Offering. Jurnal Akuntansi Udayanan

Rakhmat, Jalaluddin. 1999. Metode Penelitian Komunikasi. Bandung, PT. Remaja Rosda Karya.

Rusdin, 2006. Pasar modal, Bandung: Alfabeta

Samsul, Mohamad. 2006. Pasar Modal dan Manajemen Portofolio. Jakarta: Erlangga

Scott, William R, 2006. Financial Accounting Theory. Fourth Edition. Canada Prentice Hall

Scott, William R, 2009. Financial Accounting Theory. Fifth Edition. Canada Prentice Hall

Setyorini, dan Supriyadi .Hubungan Dinamis Antara Nilai Tukar Rupiah dan Harga Saham di Bursa Efek Jakarta Jurnal Bisnis dan Akuntansi, Vol. 5, No. 1, Juni 2001

Sjahrial, Dermawan. 2009. Manajemen Keuangan (3 th ed). Jakarta: Mitra Wacana. Media 
Suciwati dan Machfoedz. 2002. Pengaruh Risiko Nilai Tukar Rupiah Terhadap Return Saham: Studi Empiris Pada Perusahaan Manufactur Yang Terdaftar Di BEJ. Jurnal Ekonomi dan Bisnis Indonesia (17), Oktober: 347 360

Sukirno, Sadono. 2011. Makro Ekonomi Teori Pengantar. Jakarta: PT. Rajagrafindo Persada.

Sulistiawan dkk., 2012. Creative Accounting: Mengungkap Manajemen Laba dan Skandal Akuntansi, Salemba Empat, Jakarta

Sutrisno, 2007, Manajemen Keuangan, Yogyakarta: Penerbit Ekonesia.

Eduardus Tandelilin. 2007. Analisis Investasi dan Manajemen. Portofolio (Edisi. Pertama, Cetakan Kedua). Yogyakarta: BPFE

Tangkilisan dan Nogi Hessel, 2003, Manajemen Keuangan Bagi Analisis Kredit Perbankan, Yogyakarta,

Triyono. 2008. Analisis perubahan kurs rupiah Terhadap dollar amerika. Jurnal Ekonomi Pembangunan Vol. 9, No. 2, Desember 2008, hal. $156-167$

Undang-Undang Nomor 8 Tahun 1995 tentang pasar modal

Utami S, Putu Citra Heveanty; Gede Adi Yuniarta, dan Edy Sujana. 2017. Reaksi Investor Dalam Pasar Modal Terhadap Peristiwa Menguatnya Kurs Dolar Amerika Serikat Pada Nilai Tukar Rupiah (Event Study pada Peristiwa Menguatnya Kurs Dolar AS Terhadap Nilai Tukar Rupiah Tanggal 26 Agustus 2015). Journal Universitas Pendidikan Ganesha Volume 07 Nomor 01

Van Horne, James C dan John M. Wachowicz, JR. 2007. Prinsip-Prinsip Manajemen Keuangan. Jakarta: Salemba Empat

Wahyuningsih, Dwi Retno. 2007. Hubungan Praktik Manajemen Laba Dengan Reaksi Pasar Atas Pengumuman
Informasi Laba Perusahaan Manufaktur Di Bursa Efek Jakarta. Tesis Universitas Diponegoro

Wardani, Diah Kusuma, 2014. "Pengaruh Corporate Governance Terhadap Kinerja Perusahaan di Indonesia". Jurnal Fakultas Ekonomi UII: Yogyakarta

Weston, J.Fred dan Eugene F. Brigham.2008. Dasar-dasar Manajemen Keuangan (1 th ed). Jakarta: Erlangga 